\title{
Carbon and Nitrogen Economy of Developing Rabbiteye Blueberry Fruit
}

\author{
Keith T. Birkhold, Karen E. Koch, and Rebecca L. Darnell \\ Department of Fruit Crops, University of Florida, Gainesville, FL 32611 \\ Additional index words. Vaccinium ashei, fruit photosynthesis, fruit respiration, fruit development
}

\begin{abstract}
Carbon dioxide exchange, dry weight, $\mathbf{C}$, and $\mathbf{N}$ content of 'Bonita' and 'Climax' blueberry (Vaccinium ashei Reade) fruit were measured from anthesis through fruit ripening to quantify developmental changes in amounts of imported $\mathrm{C}$ and $\mathrm{N}$ required for fruit development. Net photosynthesis occurred in fruit of both rabbiteye cultivars from petal fall through color break. During this time, fruit net photosynthesis declined from $16 \mu_{m o l} \mathrm{CO}_{2} / g$ fresh weight (FW) per hour for 'Bonita' and $22 \mu \mathrm{mol} \mathrm{CO}_{2} / \mathrm{g} \mathrm{FW}$ per hour for 'Climax' to $0.2 \mu \mathrm{mol} \mathrm{CO}_{2} / \mathrm{g} \mathrm{FW}$ per hour for both. Dark respiration for both cultivars declined following petal fall from $16 \mu \mathrm{mol} \mathrm{CO}_{2} / \mathrm{g}$ FW per hour to 3 $\mu \mathrm{mol} \mathrm{CO}_{2} / \mathrm{g}$ FW per hour before increasing at fruit ripening to $9 \mu \mathrm{mol} \mathrm{CO}_{2} / \mathrm{g} \mathrm{FW}$ per hour. Fruit $\mathrm{C}$ content was constant at $0.43 \mathrm{mg} \mathrm{C} / \mathrm{mg}$ dry weight (DW) throughout development, while $\mathrm{N}$ content declined from $0.05 \mathrm{mg} \mathrm{N} / \mathrm{mg}$ DW at petal fall to $0.01 \mathrm{mg} \mathrm{N} / \mathrm{mg}$ DW at ripeness. DW accumulation and respiration accounted for $63 \%$ and $37 \%$, respectively, of the total $\mathrm{C}$ requirement for fruit development. Fruit photosynthesis was estimated to contribute $15 \%$ of the total $\mathrm{C}$ required for fruit development in both cultivars; however, fruit photosynthesis supplied $50 \%$ of the $\mathrm{C}$ required during the first $\mathbf{1 0}$ days after bloom and $\mathbf{8 5 \%}$ during the $\mathbf{5}$ days after petal fall. This large, early contribution of $\mathbf{C}$ from fruit photosynthesis may aid in the establishment of fruit until the current season's vegetative growth can supplement plant carbohydrate reserves in providing $\mathbf{C}$ for fruit development.
\end{abstract}

Rabbiteye blueberries are the major blueberry species commercially grown in the southeastern United States (Crocker and Willis, 1989). Depending on the cultivar and/or chilling regime, floral budbreak in rabbiteye blueberries occurs before or concomitantly with vegetative budbreak (Darnell and Davies, 1990). As a result, some cultivars have a period during the spring when no leaves are present to support fruit development. It is during this initial stage of reproductive growth that flowers and young fruit must meet their $\mathrm{C}$ requirement through flower or fruit photosynthesis and/or the remobilization and importation of carbohydrates stored during the previous growing season.

Fruit photosynthesis occurs in a wide range of plant species (Blanke and Lenz, 1989; Flinn et al., 1977) and may supply a significant portion of the total fruit $\mathrm{C}$ requirement in some plants (Bazzaz et al., 1979). Although there is a substantial amount of work on fruit photosynthesis (Bean and Todd, 1960; Bean et al., 1963; Flinn et al., 1977; Jones, 1981; Koch and Alleweldt, 1978), there is limited information on the contribution of fruit photosynthesis to the $\mathrm{C}$ budget of the developing fruit. Kappes (1985) reported that fruit photosynthesis contributes $\approx 11 \%$ of the total fruit requirement in sour cherry (Prunus cerasus L.), and Bazzaz et al. (1979) reported that $\approx 20 \%$ of the fruit $\mathrm{C}$ requirement in hackberry (Celtis occidentalis L.) trees and wild black cherry (Prunus serotina) trees was supplied by fruit photosynthesis. The contribution of fruit photosynthesis to blueberry fruit $\mathrm{C}$ balance is unknown. However, low rates of fruit respiration compared with other fruits (Hardenburg et al., 1986), the maintenance of green pigmentation throughout the bulk of development, and the low surface area : volume ratio of blueberry fruit suggest that the contribution of fruit photosynthesis to the total $\mathrm{C}$ budget of these developing fruit may be significant.

Before vegetative budbreak in the spring, $\mathrm{C}$ demands of developing fruit not met by fruit photosynthesis must be satisfied by remobilization of stored carbohydrates. The degree of reserve

Received for publication 22 Apr. 1991. Accepted for publication 15 Aug. 1991. Univ. of Florida Journal Series no. R-01713. The cost of publishing this paper was defrayed in part by the payment of page charges. Under postal regulations, this paper therefore must be hereby marked advertisement solely to indicate this fact. carbohydrate use by reproductive growth may vary, depending on the crop load, fruit growth rate, and initiation of net carbohydrate export from new leaves. In shoots and roots of apple (Malus domestics Borkh.) and peach [Prunus persica (L.) Batsch.], carbohydrates declined until 8 weeks after budbreak, with replenishment of the carbohydrate pool in peach beginning 9 weeks after budbreak (Oliveira and Priestley, 1988; Stassen et al., 1981). Carbohydrate levels in roots of sweet cherry [Prunus avium (L.) L.] declined rapidly during full bloom and did not increase significantly until after fruit harvest (Keller and Loescher, 1989). Kappes (1985) speculated that a portion of the remobilized carbohydrate reserve may be important in supplying $\mathrm{C}$ to fruit during stage I of sour cherry fruit development. Quinlan and Preston (1968) found that apple flowering and early fruit development partially depend on carbohydrate reserves, although spur leaf photosynthesis supplies some of the required C. New vegetative growth also imports $\mathrm{C}$, thus initially competing with fruit for remobilized carbohydrates. Hansen (1971) found that DW gain of the first five to six leaves in apple depends on carbohydrate reserves, and Hansen and Grauslund (1973) estimated that up to $75 \%$ of the carbohydrate reserves present in apple at budbreak were used for respiration in the development of new leaves, shoots, and fruit in the early spring. Since the initiation of reproductive growth occurs concomitantly with or before vegetative growth in rabbiteye blueberry, there may be substantial competition between vegetative and reproductive sinks for carbohydrate reserves.

Vegetative and reproductive competition for reserves may extend beyon ${ }^{\text {d }}$ carbohydrates to other essential substances, such as N. Nitrogen mobilized to developing tissues in the early spring in almond [Prunus dulcis (Mill.) D.A. Webb], European plum (Prunus domestics L.), and apricot (Prunus armenica L.) comes predominantly from reserves, with relatively little root uptake of applied $\mathrm{N}$ occurring during the dormant months (Weinbaum et al., 1978, 1980, 1984). Uptake of exogenously supplied ${ }^{15} \mathrm{~N}$ and accumulation in reproductive and vegetative tissue in almond corresponds with the period of shoot elongation and leaf expansion (Weinbaum et al., 1984). Early reproductive

Abbreviations: DAA, days after anthesis; DW, dry weight; FW, fresh weight. 
growth in blueberry probably depends on stored $\mathrm{N}$ reserves; furthermore, competition for $\mathrm{N}$ reserves may arise, depending on the relative timing of vegetative and reproductive growth.

The purpose of the present study was to determine the developmental changes in the total $\mathrm{C}$ and $\mathrm{N}$ requirement for fruit development in rabbiteye blueberry. Additionally, the $\mathrm{C}$ source, i.e., fruit photosynthesis vs. imported $\mathrm{C}$, was determined, and a $\mathrm{C}$ budget during fruit development was calculated. Fruit photosynthesis, respiration, FW and DW gain, and $\mathrm{C}$ and $\mathrm{N}$ accumulation were measured throughout development for two rabbiteye blueberry cultivars, Bonita and Climax. These cultivars were chosen based on differences in budbreak pattern; floral and vegetative budbreak occur concomitantly in 'Bonita', while floral budbreak precedes vegetative budbreak in 'Climax'. These differences in timing of floral and vegetative budbreak offer the opportunity to determine the effect of temporal differences in reproductive and vegetative competition on $\mathrm{C}$ and $\mathrm{N}$ use, as well as fruit photosynthesis.

\section{Materials and Methods}

Plant material. 'Bonita' and 'Climax' rabbiteye blueberries were propagated by softwood cuttings in Spring 1989, potted into 22-liter containers filled with a 1 peat : 1 pine bark mix, and grown outdoors in Gainesville, Fla. Plants were watered daily, and fertilized with Peter's $20 \mathrm{~N}-5.6 \mathrm{P}-11 \mathrm{~K}$ water soluble fertilizer every 2 weeks during the growing season. By the beginning of the experiment, plants had multiple canes, ranging in height from 30 to $45 \mathrm{~cm}$, and there were 15 to 20 flower clusters per plant.

Carbon dioxide exchange. In Mar. 1990, before anthesis, flower custers from each cultivar were thinned to two flowers per cluster and tagged. Net $\mathrm{CO}_{2}$ exchange of flowers and fruit was monitored under light $\left[1000 \mu \mathrm{mol} \cdot \mathrm{m}^{-2} \cdot \mathrm{s}^{-1}\right.$ photosynthetic photon flux (PPF) emitted from a 400-W high-pressure sodium vapor lamp (Lucalox)] and dark conditions in the laboratory. Ten flowers per fruit cluster were measured at each of 11 sampling dates from anthesis through fruit ripening. At each sampling, the thinned flower or fruit cluster was enclosed in a 104$\mathrm{ml}$ plexiglass chamber and flushed for $10 \mathrm{~min}$ with ambient air at 1 liter. $\min ^{-1}$. The chamber was then closed and fruit photosynthesis was measured by quantifying the decrease in $\mathrm{CO}_{2}$ concentration after $30 \mathrm{~min}$ in the closed system. Temperatures in the light were maintained at $25 \pm 2 \mathrm{C}$. For measurements of dark respiration, the chamber was covered with foil and black plastic and equilibrated for $10 \mathrm{~min}$ in an open system. The chamber was then closed and respiration was measured by quantifying the increase in $\mathrm{CO}_{2}$ concentration after $30 \mathrm{~min}$ in the closed system. Temperatures in the dark were maintained at 21 $\pm 2 \mathrm{C}$. Analysis of $\mathrm{CO}_{2}$ samples was by gas chromatography (Fisher Scientific, Pittsburgh; Model 1200), using an 80 to 100 mesh Colmpak PQ column, injector and column temperatures of $60 \mathrm{C}$, and a thermal conductivity detector.

Fruit growth and carbon and nitrogen content. After taking fruit $\mathrm{CO}_{2}$ exchange measurements, fruit were harvested and FW and DW determined (oven-dried at 60C for 10 days). Dried fruit were ground "to a fine powder using a mortar and pestle, and 3mg subsamples were analyzed for $\mathrm{C}$ and $\mathrm{N}$ content by combustion, oxidation, and quantification on a Carlos Erba Model NA 1500 gas chromatography (Carlos Erba Strumentavione, Milan, Italy), using a chromium oxide/cobaltous-cobaltic oxide column at $1010 \mathrm{C}$ in tandem with a copper column at $650 \mathrm{C}$, and a thermal conductivity detector.

Calculations of carbon budget. Carbon dioxide exchange data in the light and dark were extrapolated to a per-day basis assuming a 12-h photoperiod, saturating PPF, and mean temperatures of 25/21C (day/night).

The average daily $\mathrm{C}$ use $(\mathrm{C}$ accumulation plus respiratory $\mathrm{C}$ loss) for a given stage of fruit development (between days $t_{1}$ and $\mathrm{t}_{2}$ ) was calculated from data on fruit $\mathrm{CO}_{2}$ exchange, dry weight gain, and $\mathrm{C}$ content. The average daily $\mathrm{C}$ accumulation (milligrams $\mathrm{C}$ per fruit per day) was calculated from measurements of total $\mathrm{C}$ content of fruit at various stages of development by:

$$
\begin{gathered}
\text { Mean daily } \mathrm{C} \text { accum. }=[\text { total } \mathrm{C} \text { content }- \\
\text { total } \left.\mathrm{C} \text { content }\left(\mathrm{t}_{1}\right)\right] /\left(\mathrm{t}_{2}-\mathrm{t}_{1}\right) .
\end{gathered}
$$

The daily respiration of the fruit was calculated by multiplying the hourly dark $\mathrm{CO}_{2}$ exchange rate by 24 . The average daily respiration (milligrams $C$ per fruit per day) between $t_{1}$ and $t_{2}$ was calculated by:

$$
\begin{aligned}
& \text { Mean daily resp. }=\left[\text { daily resp. }\left(\mathrm{t}_{1}\right)+\right. \\
& \text { daily } \left.\operatorname{resp} .\left(\mathrm{t}_{2}\right)\right] / 2 .
\end{aligned}
$$

Therefore, the average daily $\mathrm{C}$ use (milligrams $\mathrm{C}$ per fruit per day) was the sum of the average daily $\mathrm{C}$ accumulation and the average daily respiration (Eqs. [1] $+[2])$.

The contribution of $\mathrm{C}$ from daily fruit photosynthesis was calculated as the difference between net $\mathrm{CO}_{2}$ exchange in the light and net $\mathrm{CO}$, exchange in darkness, multiplied by the photoperiod (i.e., 12). The average daily fruit photosynthetic contribution (milligrams $\mathrm{C}$ per fruit per day) between $\mathrm{t}_{1}$ and $\mathrm{t}_{2}$ was calculated by:

$$
\begin{aligned}
& \text { Mean daily fruit PS cont. }=\left[\text { daily fruit PS }\left(\mathrm{t}_{1}\right)+\right. \\
& \text { daily fruit } \left.\operatorname{PS}\left(\mathrm{t}_{2}\right)\right] / 2
\end{aligned}
$$

This amount was subtracted from the average daily $\mathrm{C}$ use to determine the amount of $\mathrm{C}$ imported.

\section{Results}

Fruit development. Bloom of both 'Bonita' and 'Climax' rabbiteye blueberries began on 9 Mar., with petal fall occurring 4 DAA, and fruit maturity at 75 DAA. FW and DW were similar for both cultivars up to 25 DAA (Fig. 1). By 35 DAA, FW and DW of 'Bonita' fruit were twice those of 'Climax' fruit. This difference continued throughout fruit development. Mean FW at ripeness was $1.8 \mathrm{~g}$ for 'Bonita' and $0.9 \mathrm{~g}$ for 'Climax'.

Carbon dioxide exchange of attached fruit. Fruit of both cultivars exhibited net photosynthesis in the light at $25 \mathrm{C}$ until fruit color break, which occurred between 65 and 75 DAA (Fig. 2). Net photosynthesis of 'Bonita' fruit decreased from a maximum of $16 \mu \mathrm{mol} \mathrm{CO} / \mathrm{g} \mathrm{FW}$ per hour the day after petal fall to 0.2 $\mu \mathrm{mol} \mathrm{CO}_{2} / \mathrm{g} \mathrm{FW}$ per hour by 65 DAA. 'Climax' displayed similar net photosynthetic rates, although the maximum rate immediately following petal fall was higher $(22 \mu \mathrm{mol} \mathrm{CO} / \mathrm{g} \mathrm{FW}$ per hour).

Developmental changes in dark respiration patterns for fruit of both cultivars were also similar (Fig. 2). Respiration rates averaged $17 \mu \mathrm{mol} \mathrm{CO}_{2} / \mathrm{g} \mathrm{FW}$ per hour while the petal remained attached, decreased transiently (less negative values) at petal fall, then increased again to $16 \mu \mathrm{mol} \mathrm{CO} / \mathrm{g} \mathrm{FW}$ per hour at 10 DAA. During the subsequent period of fruit expansion, the respiratory rates again declined, dropping to $\approx 3 \mu \mathrm{mol} \mathrm{CO} / \mathrm{g} \mathrm{FW}$ per hour before the rise at fruit color break.

Carbon requirement of developing fruit. Carbon content of fruit averaged $43 \%$ of the fruit dry weight throughout development (data not shown). The average daily fruit $\mathrm{C}$ accumulation displayed a 


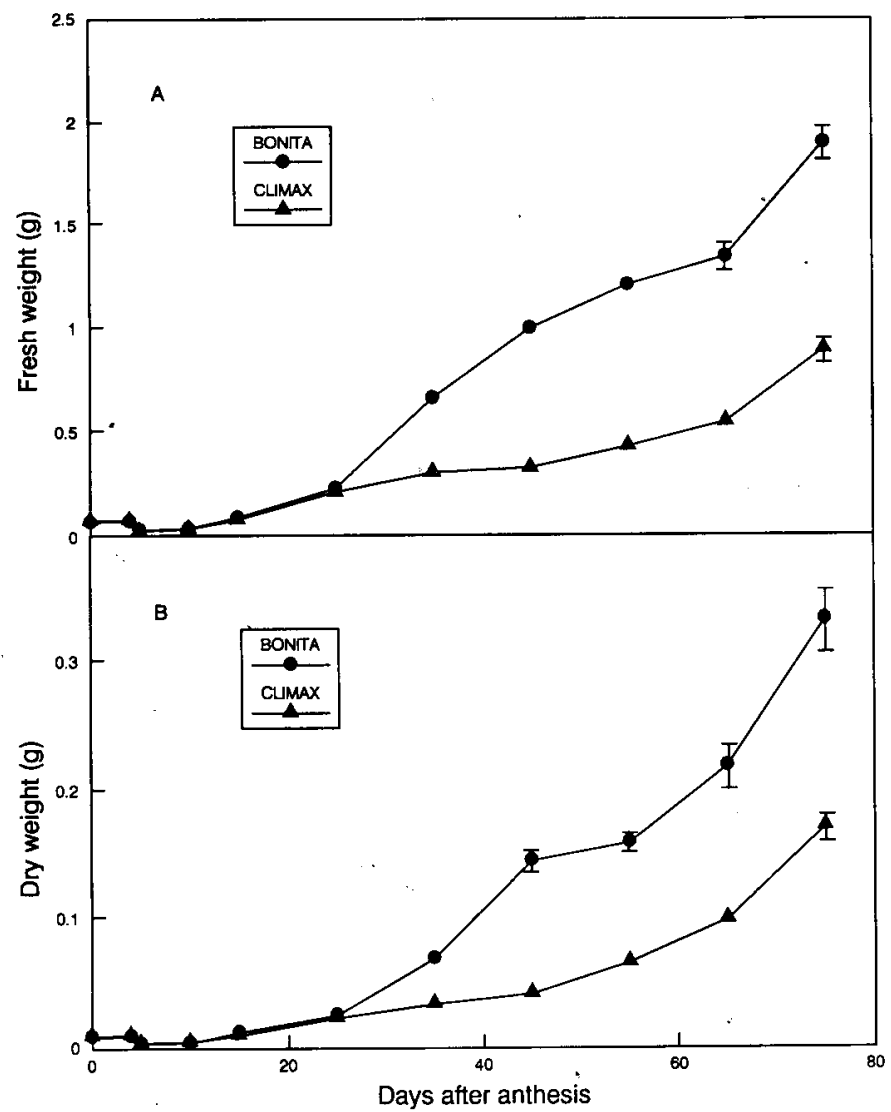

Fig. 1. Fresh (A) and dry (B) weights of 'Bonita' and 'Climax' rabbiteye blueberry fruit from anthesis to ripening (means $\pm \mathrm{SE}, \mathrm{n}=$ 20, SE bars present only when larger than symbol).

clear double sigmoidal pattern for 'Bonita' fruit, with stage I occurring between bloom and 45 DAA, stage II from 45 to 55 DAA, and stage III from 55 to 75 DAA (Fig. 3). The double sigmoidal pattern was not as clearly defined for 'Climax' fruit, although a slight reduction in the rate of $\mathrm{C}$ accumulation, characteristic of the expansion that takes place during stage II, appears to occur between 35 and 45 DAA. The negative rate of $\mathrm{C}$ accumulation displayed by both cultivars between 4 and 5 DAA was due to the C lost by petal fall (Fig. 3).

The respiratory component of the fruit $\mathrm{C}$ requirement reached its maximum at fruit ripeness, with rates of $5.3 \mathrm{mg} \mathrm{C}$ per fruit per day for 'Bonita' and $2.8 \mathrm{mg} \mathrm{C}$ per fruit per day for 'Climax' (Fig. 3). Contribution of fruit respiration to the total $\mathrm{C}$ used throughout development was $21 \%$ in stage I, $44 \%$ in stage II, and $47 \%$ in stage III for 'Bonita', and $36 \%, 45 \%$, and $37 \%$ correspondingly for 'Climax' (Table 1).

The average daily fruit $\mathrm{C}$ use (DW gain + respiratory loss) mirrored the developmental changes in rates of DW C accumulation. Maximum rates of total $\mathrm{C}$ use in 'Bonita' fruit peaked at 35 to 45 DAA (end of stage I) at $4.5 \mathrm{mg} \mathrm{C}$ per fruit per day, and 65 to 75 DAA (fruit ripening) at $9.0 \mathrm{mg} \mathrm{C}$ per fruit per day (Fig. 3). 'Climax' fruit displayed maximum rates of $0.9 \mathrm{mg} \mathrm{C}$ per fruit per day at 15 to $25 \mathrm{DAA}$ and $4.5 \mathrm{mg} \mathrm{C}$ per fruit per day at 65 to 75 DAA. The total amount of $\mathrm{C}$ required for 'Bonita', the larger-fruited cultivar, was $227 \mathrm{mg} \mathrm{C}$ per fruit, twice as much as that used by 'Climax' fruit (110 mg C per fruit). For both cultivars, fruit $\mathrm{C}$ accumulation accounted for $63 \%$ of the total $\mathrm{C}$ requirement, with respiratory $\mathrm{C}$ loss comprising the remaining $37 \%$

Carbon supply of developing fruit. The photosynthetic com-

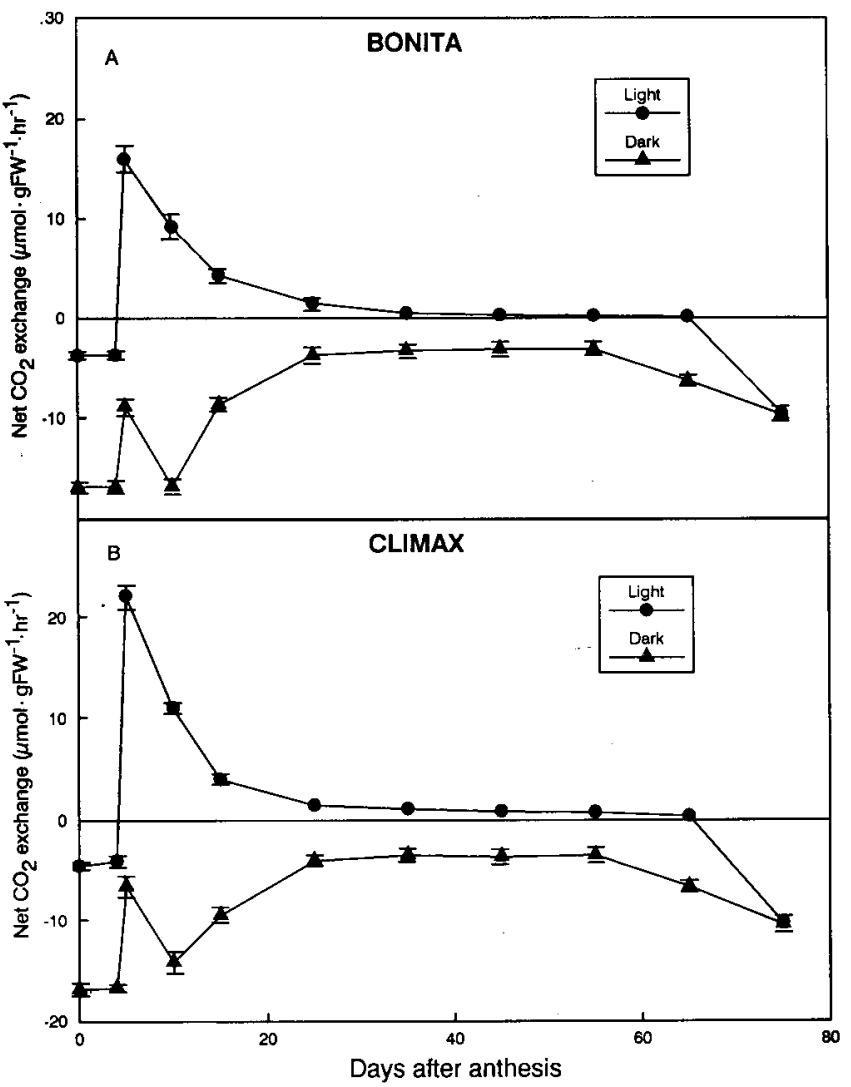

Fig. 2. Net CO, exchange rates for 'Bonita' (A) and 'Climax' (B) rabbiteye blueberry fruit in light $\left(1000 \mu \mathrm{mol} \cdot \mathrm{m}^{-2} \cdot \mathrm{s}^{-1} \mathrm{PPF}, 25 \mathrm{C}\right)$ and darkness (21C) from anthesis to ripening. Intact, attached fruit were used for all measurements (means $\pm \mathrm{SE}, \mathrm{n}=10$, SE bars present only when larger than symbol).

ponent of the fruit $\mathrm{C}$ supply reached its maximum just before fruit color break, with rates of $1.2 \mathrm{mg} \mathrm{C}$ per fruit per day for 'Bonita' and $0.6 \mathrm{mg} \mathrm{C}$ per fruit per day for 'Climax' (Fig. 3). Rates of $\mathrm{C}$ import were maximal for both cultivars after color break, with 'Bonita' importing $8.0 \mathrm{mg} \mathrm{C}$ per fruit per day and 'Climax' importing $4.2 \mathrm{mg} \mathrm{C}$ per fruit per day. From anthesis through fruit ripening, fruit photosynthesis contributed $14 \%$ of the total C demand of 'Bonita' fruit, with $12 \%$ in stage I, $24 \%$ in stage II, and $13 \%$ in stage III being supplied from fruit photosynthesis (Table 1). 'Climax' fruit photosynthesis supplied a total of $15 \%$ of the fruit $\mathrm{C}$ requirement throughout development, with $24 \%, 28 \%$, and $11 \%$ being supplied for the three developmental stages, respectively. During the first 10 days of fruit development for both cultivars, $50 \%$ of the total $\mathrm{C}$ used was met through fruit photosynthesis, and from 5 to 10 DAA, $85 \%$ of the total $\mathrm{C}$ required was supplied via fruit photosynthesis (Table 2).

Nitrogen concentration of developing fruit. Fruit $\mathrm{N}$ concentration fluctuated throughout development, increasing from 0.03 $\mathrm{mg} \mathrm{N} / \mathrm{mg} \mathrm{DW}$ at anthesis to $\approx 0.05 \mathrm{mg} \mathrm{N} / \mathrm{mg} \mathrm{DW}$ just after petal fall on day 5 (Fig. 4). Fruit $\mathrm{N}$ concentration in both cultivars declined to $\approx 0.01 \mathrm{mg} \mathrm{N} / \mathrm{mg} \mathrm{DW}$ at maturity, with the largest change occurring between 5 and 25 DAA.

Nitrogen requirement of developing fruit. 'Bonita' fruit accumulated $\mathrm{N}$ at maximal rates of $0.09 \mathrm{mg} \mathrm{N}$ per fruit per day at the end of stage I ( 35 to $45 \mathrm{DAA}$ ), and $0.11 \mathrm{mg} \mathrm{N}$ per fruit per day at fruit ripening (65 to 75 DAA) (Fig. 5). 'Climax' fruit exhibited peaks of $0.04 \mathrm{mg} \mathrm{N}$ per fruit per day in the middle 


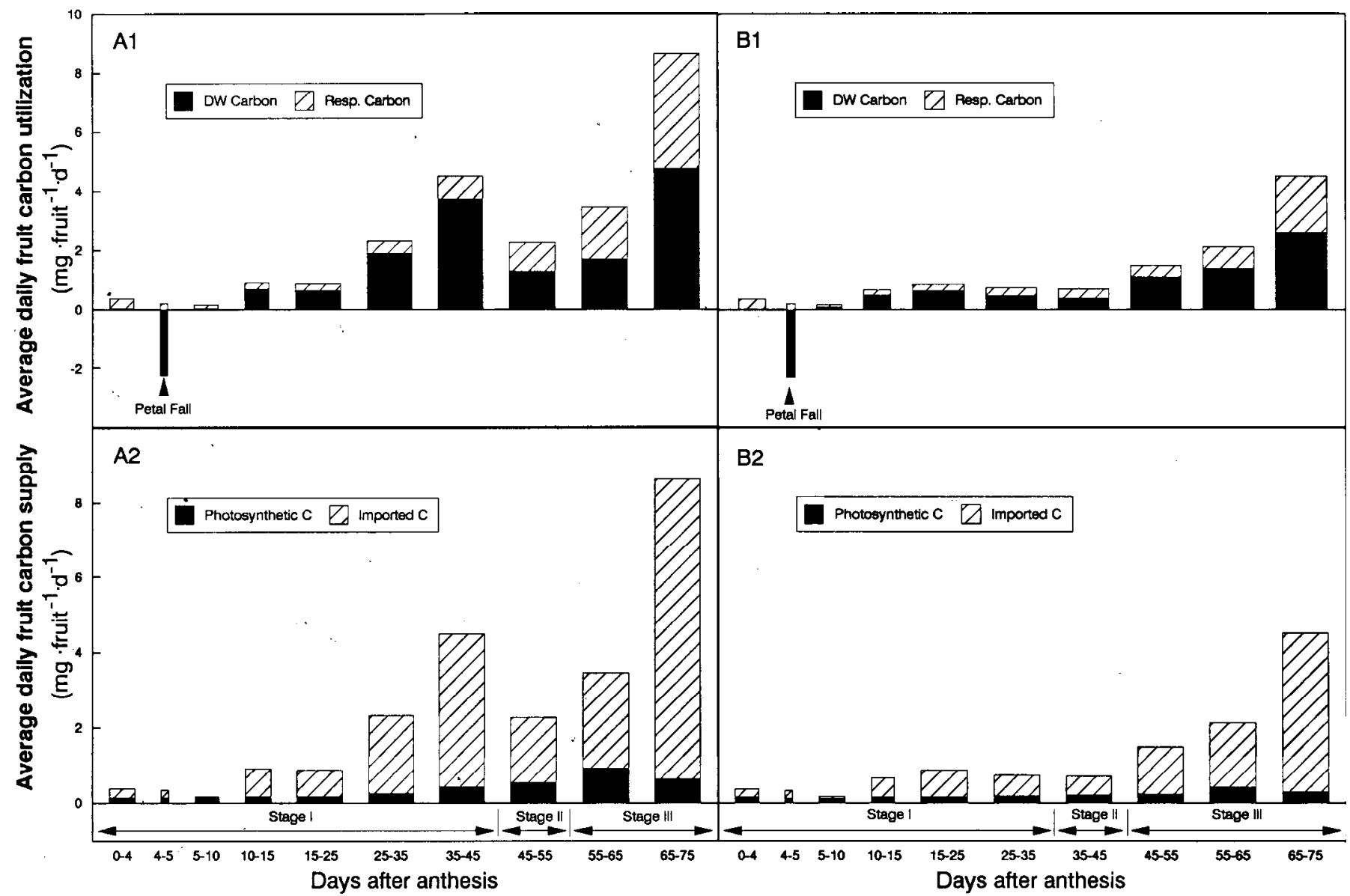

Fig. 3. Calculated rate of $\mathrm{C}$ use and $\mathrm{C}$ supply for 'Bonita' (A) and 'Climax' (B) rabbiteye blueberry fruit from anthesis to ripening: (Al) and (B1) average daily fruit $\mathrm{C}$ use (dry weight accumulation + respiratory loss), (A2) and (B2) average daily fruit $\mathrm{C}$ supply (fruit photosynthesis + imported C). Data are based on a 12-h photoperiod and 25/21C light/dark temperatures.

Table 1. Estimated developmental changes in $\mathrm{C}$ budget for developing fruit of 'Bonita' and 'Climax' rabbiteye blueberries.

\begin{tabular}{|c|c|c|c|c|c|c|c|c|}
\hline \multirow[b]{2}{*}{ Criterion } & \multicolumn{4}{|c|}{ Bonita } & \multicolumn{4}{|c|}{ Climax } \\
\hline & $\begin{array}{c}\text { Stage I } \\
(0-45 \text { DAA })\end{array}$ & $\begin{array}{c}\text { Stage II } \\
(45-55 \text { DAA }) \\
\end{array}$ & $\begin{array}{c}\text { Stage III } \\
(55-75 \text { DAA })\end{array}$ & Total & $\begin{array}{c}\text { Stage I } \\
(0-35 \text { DAA })\end{array}$ & $\begin{array}{c}\text { Stage II } \\
\text { (35-45 DAA) }\end{array}$ & $\begin{array}{c}\text { Stage III } \\
(45-75 \text { DAA })\end{array}$ & Total \\
\hline \multicolumn{9}{|l|}{ Carbon cost } \\
\hline Dry wt & $66.4^{z}(79)^{y}$ & $12.7(56)$ & $64.4(53)$ & $143.5(63)$ & $13.9(63)$ & $3.9(55)$ & $50.7(63)$ & $68.5(62)$ \\
\hline Respiratory loss & $17.3(21)$ & $9.9(44)$ & $56.4(47)$ & $83.6(37)$ & $7.9(36)$ & $3.2(45)$ & $30.2(37)$ & $41.3(38)$ \\
\hline Total & 83.7 & 22.6 & 120.8 & 227.1 & 21.8 & 7.1 & 80.9 & 109.8 \\
\hline \multicolumn{9}{|l|}{ Carbon supply } \\
\hline Fruit photosynthesis & $10.4(12)$ & $5.4(24)$ & $15.6(13)$ & $31.4(14)$ & $5.2(24)$ & $2.0(28)$ & $9.3(11)$ & $16.5(15)$ \\
\hline Imported & $73.3(88)$ & $17.2(76)$ & $105.2(87)$ & $195.7(86)$ & $16.6(76)$ & $5.1(72)$ & $71.6(89)$ & $93.3(85)$ \\
\hline
\end{tabular}

${ }^{2}$ Values represent milligrams $\mathrm{C}$ per fruit required for each stage of development. Budget assumes $25 / 21 \mathrm{C}$ for day/night and a 12 -h photoperiod. ${ }^{y}$ Values in parentheses represent the percentage contribution to the $C$ cost or $C$ supply for each stage of development.

of stage I (10 to 15 DAA), with a second peak of $0.06 \mathrm{mg} \mathrm{N}$ per fruit per day occuring in the middle of stage III (55 to 65 DAA). A negative $\mathrm{N}$ accumulation rate occurred between 4 and 5 DAA as a result of petal fall. The total $\mathrm{N}$ requirement of 0.76 $\mathrm{mg} \mathrm{N}$ for production of a 25-day-old fruit was similar for both cultivan. From 25 DAA to fruit ripeness, 'Bonita' and 'Climax' fruit accumulated $2.63 \mathrm{mg} \mathrm{N}$ and $1.46 \mathrm{mg} \mathrm{N}$, respectively.

\section{Discussion}

The divergence between fruit DW of 'Bonita' and 'Climax' appears to be related to the timing of vegetative budbreak. Differences in vegetative growth of the cultivars were apparent at full bloom (9 Mar.), when 'Bonita' was beginning to break vegetative buds, while 'Climax' showed no vegetative budbreak. By 5 Apr. (27 DAA), the leaf canopy for 'Bonita' was well established, while 'Climax' was only beginning to leaf out. By 1 May (52 DAA), both cultivars had a strong vegetative canopy established. Fruit FW and DW were nearly identical up to 25 DAA, when 'Bonita' fruit began to rapidly increase in FW and DW. The rate of DW gain of 'Climax' fruit did not increase until 45 DAA. In both cultivars, the increase in rate of fruit DW gain coincided with the establishment of the vegetative canopy.

Rabbiteye blueberry fruit maintained a net photosynthetic rate in the light from petal fall through fruit color break, with $\mathrm{CO}_{2}$ 
Table 2. Estimated developmental changes in C budget during stage I growth of 'Bonita' and 'Climax' rabbiteye blueberries.

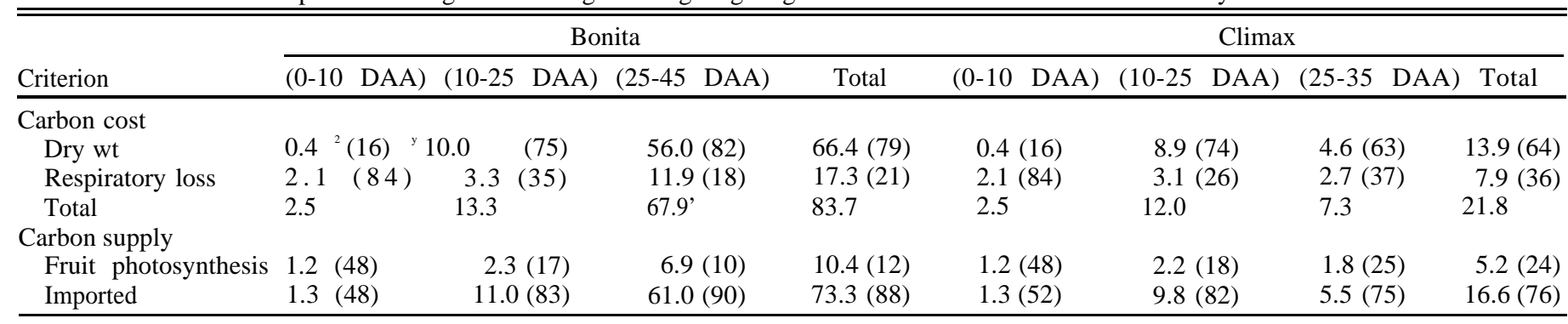

${ }^{2}$ Values, represent milligrams $\mathrm{C}$ per fruit required for periods during stage I of development.

${ }^{y}$ Values in parentheses represent the percentage contribution to the $\mathrm{C}$ cost or $\mathrm{C}$ supply for periods during stage I of development.

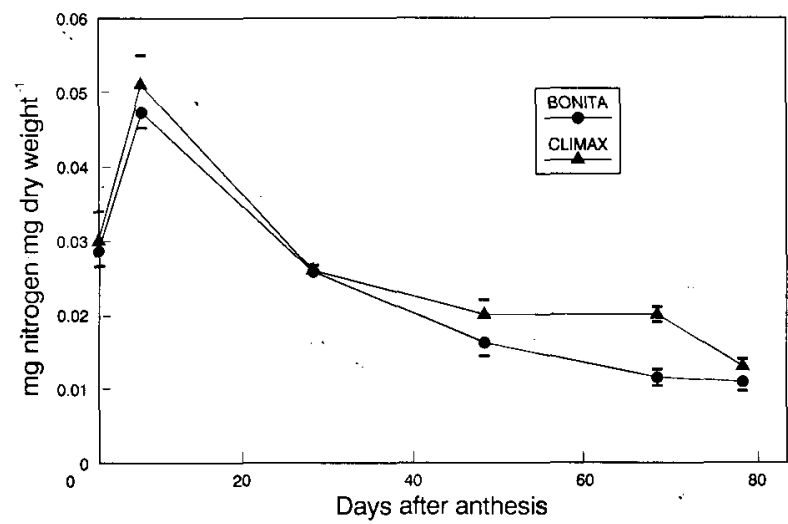

Fig. 4. Nitrogen concentration of developing 'Bonita' and 'Climax' rabbiteye blueberry fruit from anthesis to ripening (means $\pm \mathrm{SE}$, $\mathrm{n}=5)$.

being released faster than it was consumed only when the petals were attached or when chlorophyll degradation occurred at color break. Net photosynthesis in fruit has not been previously reported to occur throughout as extensive a portion of fruit development as was shown here for rabbiteye blueberries. In fact, net photosynthesis has not been observed at any point in development in many fruits; including olive (Olea europaea L.) (Proietti and Tombesi, 1990), apple (Blanke and Lenz, 1989; Jones, 1981), sour cherry (Kappes and Flore, 1990), and grape (Vitis vinifera L.) (Koch and Alleweldt, 1978; Kriedemann, 1968). Recently, Flore and Hancock (1990) presented data on highbush (V. corymbosum) blueberry fruit photosynthesis that further substantiated the occurrence of net $\mathrm{CO}_{2}$ assimilation. However, maximum photosynthetic rates for these highbush blueberry fruit were $0.6 \mu \mathrm{mol} / \mathrm{g} \mathrm{DW}$ per sec $(\approx 216 \mu \mathrm{mol} / \mathrm{g} \mathrm{FW}$ per hour), which is $\approx 10$ times as high as recorded for rabbiteye blueberries in this study. The reason for this difference is unclear, although it may reflect differences in environmental factors during measurements, as well as species differences.

Fruit dark respiration rates of $3.0 \mu \mathrm{mol} \mathrm{CO}_{2} / \mathrm{g} \mathrm{FW}$ per hour, observed after 25 DAA, are consistent with previous studies on blueberry fruit. Ismail and Kender (1969) and Frenkel (1972) reported that green highbush blueberry fruits respired between 0.7 and $1.6 \mu \mathrm{mol} \mathrm{CO} / \mathrm{g} \mathrm{FW}$ per hour. Windus et al. (1976) estimated dark respiration for green fruits of 'Lateblue' and 'Bluecrop' highbush blueberry ranged between 1.3 and $2 \mu \mathrm{mol}$ $\mathrm{CO}_{2} / \mathrm{g}$ FW per hour. Respiratory rates of blueberry fruit before 17 days after petal fall have not been previously reported. In the present study, two maxima in fruit respiration rates were found. The first $(16.7 \mu \mathrm{mol} \mathrm{CO} / \mathrm{g}$ FW per hour) occurred at 4 DAA and was probably due to a high respiratory rate of the

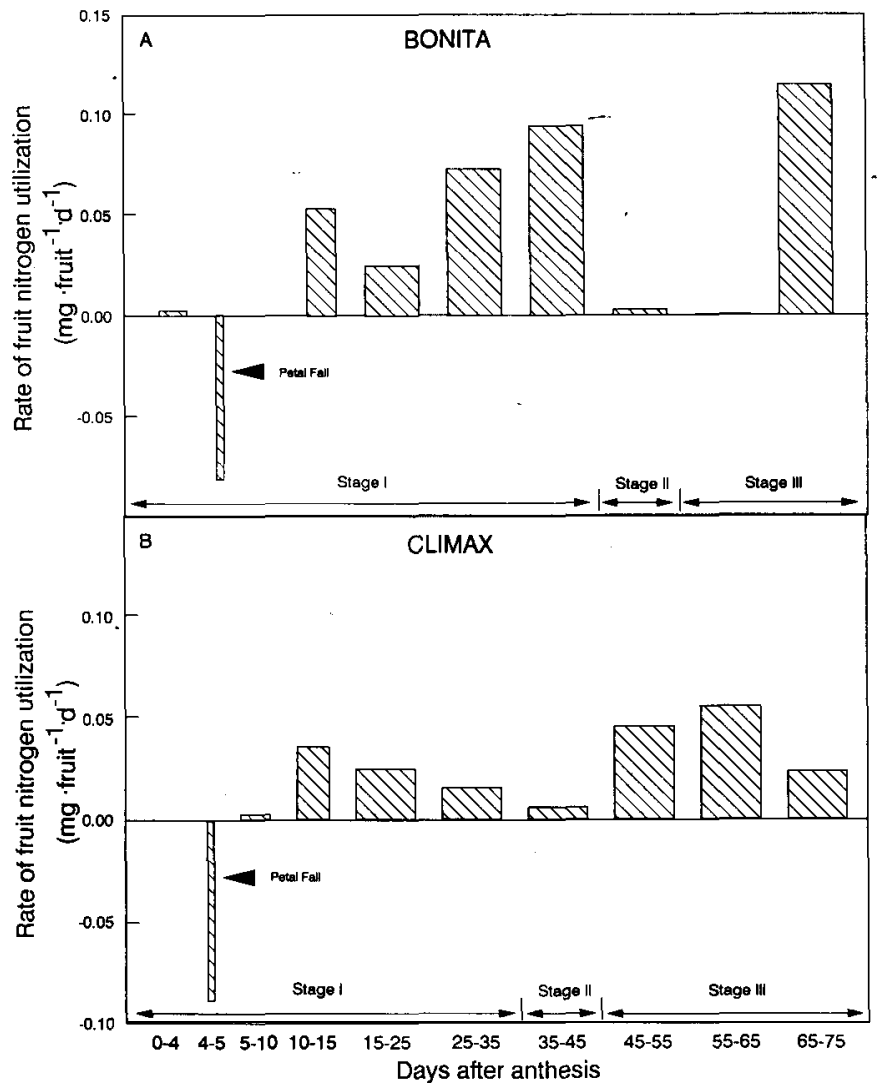

Fig. 5. Calculated $\mathrm{N}$ use rates for 'Bonita' (A) and 'Climax' (B) blueberry fruit from anthesis to ripening.

petal, since the rate fell with petal drop. The second peak (16.0 $\mu \mathrm{mol} \mathrm{CO}_{2} / \mathrm{g} \mathrm{FW}$ per hour) occurred 10 DAA and may coincide with rapid cell division.

Average rates of $\mathrm{C}$ accumulation and rates of $\mathrm{CO}_{2}$ exchange were used to estimate budgets for fruit $\mathrm{C}$ use and supply. The budgets assumed a 12-h photoperiod (natural photoperiod during fruit development in Florida is 12 to $14 \mathrm{~h}$ ) and constant day and night temperatures of 25 and $21 \mathrm{C}$, respectively. Daily maxima of 25 to $31 \mathrm{C}$ and night minima of 11 to $17 \mathrm{C}$ occurred during fruit development in this study; therefore, the simplified model presented here overestimates respiration in darkness and underestimates the respiration in the light relative to field conditions. Additionally, the model is based on saturating PPF throughout fruit development, overestimating the fruit photosynthetic contribution relative to field conditions. Nonetheless, the model does represent effects of stage of fruit development on C use and supply and provides a framework on which future work examining environmental influences can based. 
Fruit photosynthesis was estimated to contribute a significant portion $(\approx 85 \%)$ of the total fruit $\mathrm{C}$ requirement from 5 to 10 DAA. At this stage, the vegetative canopies have not formed, and the young fruit would be more fully exposed to saturating PPF. Thus, the model estimation of fruit photosynthesis would be closer to field conditions than at later stages of development. During this time, fruit were nearly self-sufficient with respect to $\mathrm{C}$ demand, and only after 10 to 15 days did they begin to rely mainly on imported $\mathrm{C}$. By this time, the earliest formed new leaves of 'Bonita' were approaching full expansion and presumably were exporting carbohydrates to fruit. Preliminary evidence indicates that net carbohydrate export occurs before full leaf expansion in blueberry (K.T.B. and R. L. D., unpublished data), as it does in apple (Johnson and Lakso, 1986) and sweet cherry (Kappes and Flore, 1989). 'Climax', however, had no new vegetative growth at this time and thus relied solely on reserve carbohydrates. Further, as vegetative budbreak began in 'Climax' ( $\approx 25$ DAA), it competed directly with the increased demand by fruit for imported C. In 'Bonita', the peak C demand by vegetative growth probably occurred during the time that fruit were supplying most of their own C. Thus, there may have been less competition for carbohydrates during the early stages of fruit development. Increased fruit size in 'Bonita' may be a consequence of this difference in the timing of vegetative growth between the two cultivars. A primary factor responsible for the larger fruit size of 'Bonita' compared with 'Climax' maybe an increase in cell number, which is a major determinant of fruit size in apple (Westwood et al., 1967). However, further work is necessary to determine if cell number differs between these two cultivars.

Although fruit, $\mathrm{N}$ concentration changed throughout development, there was no effect of differences in timing of vegetative and floral budbreak on $\mathrm{N}$ concentration in flowers or fruits. The increase in fruit $\mathrm{N}$ concentration that occurred at petal fall suggests that the $\mathrm{N}$ concentration in petals is lower than in the rest of the fruit. The decline in percent $\mathrm{N}$ of fruit following petal fall suggests alterations in the, composition of developing fruit and/or seed, as the percent of N-containing compounds, such as proteins ad/or amino acids, declines. Large amounts of $\mathrm{N}$ were not rapidly imported into developing rabbiteye blueberry fruit, which differs from nut crops such as almond (Weinbaum and Muroaka, 1986) and pecan [Carya illinoensis (Wangenh.) C. Koch] (Thor and Smith, 1935). The highest rate of $\mathrm{N}$ use $(0.11 \mathrm{mg} \mathrm{N}$ per fruit per day for 'Bonita' and $0.6 \mathrm{mg} \mathrm{N}$ per fruit per day for 'Climax') corresponded to stage III, when the rate of DW accumulation was rapidly increasing. The low fruit $\mathrm{N}$ concentration of $0.01 \mathrm{mg} \mathrm{N} / \mathrm{mg} \mathrm{DW}$ observed at the end of rabbiteye fruit development is consistent with values reported for highbush blueberry fruit at commercial harvest (Retamales and Hanson, 1989).

In conclusion, fruit photosynthesis seems to supply a major portion of the $\mathrm{C}$ requirement of young rabbiteye blueberry fruit, especially during the first 5 days after petal fall. This observation, along with the differences in fruit DW accumulation between the two cultivars, indicates that there may be a physiological advantage for developmental patterns in which vegetative growth initiation occurs during the early, almost "self-sufficient" period of fruit development. In such an instance (i.e., 'Bonita'), vegetative growth can convert from import to export status before substantial $\mathrm{C}$ must be imported by fruit. Current photosynthates from leaves are also available for a greater duration of fruit development. However, fruit of cultivars that flower before vegetative budbreak (i.e., 'Climax') will compete with emerg- ing vegetative buds during the period when fruit development begins to rely primarily on imported C. Additionally, these fruit must develop for a longer period without the benefit of current photosynthates from leaves.

\section{Literature Cited}

Bazzaz, F. A., R.W. Carlson, and J.L. Harper. 1979. Contribution to reproductive effort by photosynthesis of flowers and fruits. Nature (London) 279:554-555.

Bean, R. C., G.G. Porter, and B.K. Barr. 1963. Photosynthesis and respiration in developing fruit. III. Variation in photosynthetic capacities during color changes in citrus. Plant Physiol. 38:285-290.

Bean, R.C. and G.W. Todd. 1960. Photosynthesis and respiration in developing fruits. I. ${ }^{14} \mathrm{CO}_{2}$ uptake by young orange in light and dark. Plant Physiol. 35:425-429.

Blank, M.M. and F. Lenz. 1989. Fruit photosynthesis. Plant Cell \& Environ. 12:31-46.

Crocker, T.E. and L. Willis. 1989. Survey of southern highbush and rabbiteye blueberries in Florida. Proc. Fla. State Hort. Soc. 102:204206.

Darnell, R.L. and F.S. Davies. 1990. Chilling accumulation, budbreak, and fruit set of young rabbiteye blueberry plants. HortScience 25:635-638

Flinn, A. M., C.A. Atkins, and J.S. Pate. 1977. Significance of photosynthetic and respiratory exchanges in the carbon economy of the developing pea fruit. Plant Physiol. 60:412-418.

Flore, J.A. and J.F. Hancock. 1990. Blueberry fruit photosynthesis, p. 7. In: M.M. Blanke (cd.). Carbon economy of fruits. Bonn, Germany. (Abstr.)

Frenkel, C. 1972. Involvement of peroxidase and indole-3-acetic acid oxidase isozymes from pear, tomato, and blueberry fruit in ripening. Plant Physiol. 49:757-763.

Hansen, P. 1971. "C-studies on apple trees. VII. The early seasonal growth in leaves, flowers and shoots as dependent upon current photosynthates and existing reserves. Physiol. Plant. 25:469-473.

Hansen, P. and J. Grauslund. 1973. "C-studies on apple trees. VIII. The seasonal variation and nature of reserves. Physiol. Plant. 28:2432.

Hardenburg, R. E., A.E. Watada, and C.Y. Wang. 1986. The commercial storage of fruits, vegetables, and florist and nursery stocks. U.S. Dept. Agr. Hdbk. 66.

Ismail, A.A. and W.J. Kender. 1969. Evidence of a respiratory climacteric in highbush and lowbush blueberry fruit. HortScience 4:342344.

Johnson, R.S. and A.N. Lakso. 1986. Carbon balance model of a growing apple shoot: I. Development of the model. J. Amer. Sot. Hort. Sci. 111:160-164.

Jones, H.G. 1981. Carbon exchange of developing apple (Malus pumila Mill.) fruits. J. Expt. Bet. 32:1203-1210.

Kappes, E.M. 1985. Carbohydrate production, balance and translocation in leaves, shoots and fruits of 'Montmorency' sour cherry. PhD Diss., Michigan State Univ., East Lansing.

Kappes, E.M. and J.A. Flore. 1989. Phyllotaxy and stage of leaf and fruit development influence initiation and direction of carbohydrate export from sour cherry leaves. J. Amer. Soc. Hort. Sci. 114:642648.

Kappes, E.M. and J.A. Flore. 1990. $\mathrm{CO}_{2}$ exchange and carbon balance of sour cherry fruit, p. 9. In: M.M. Blanke (cd.). Carbon economy of fruits. Bonn, Germany. (Abstr.)

Keller, W .J. and W.H. Loescher. 1989, Nonstructural carbohydrate partitioning in perennial parts of sweet cherry. J. Amer. Soc. Hort. Sci. 114:969-975.

Koch, R. and G. Alleweldt. 1978. Gas exchange of ripening grape berries. Vitis 17:30-44.

Kriedemann, P.E. 1968. Observations on gas exchange in the developing sultana berry. Austral. J. Biol. Sci. 21:907-916.

Oliveira, C.M. and C.A. Priestley. 1988. Carbohydrate reserves in deciduous fruit trees. Hort. Rev. 10:403-430. 
Proietti, P. and A. Tombesi. 1990. Changes in photosynthetic activity in olive fruits, p. 6. In: M.M. Blanke (ed.). Carbon economy of fruits. Bonn, Germany. (Abstr.)

Quinlan, J.D. and A.P. Preston. 1968. Effects of thinning blossom and fruitlets on growth and cropping of 'Sunset' apple. J. Hort. Sci. 43:373-381.

Retamales, J.B. and E.J. Hanson. 1989. Fate of ${ }^{15} \mathrm{~N}$-labeled urea applied to mature highbush blueberries. J. Amer. Soc. Hort. Sci. 114:920-923.

Stassen, P.J., D.K. Strydom, and H.W. Stindt. 1981. Seasonal changes in carbohydrate fractions of young 'Kakamas' peach trees. Agroplante 13:47-53.

Thor, C.J.B and C.L. Smith. 1935. A physiological study of seasonal changes in the composition of the pecan during fruit development. J. Agr. Res. 50:97-121.

Weinbaum, S.A., M.L. Merwin, and T.T. Muraoka. 1978. Seasonal variation in nitrate uptake efficency and distribution of absorbed nitro- gen in nonbearing prone trees. J. Amer. Soc. Hort. Sci. 103:516-519.

Weinbaum, S.A., K. Uriu, and T.T. Muraoka. 1980. Relationship between $\mathrm{K}^{15} \mathrm{NO}_{3}$ application period and ${ }^{15} \mathrm{~N}$ enrichment of apricot blossoms and developing fruit. J. Plant. Nutr. 2:699-706.

Weinbaum, S.A., I. Klein, F.E. Broadbent, W.C. Micke, and T.T. Muraoka. 1984. Use of isotopic nitrogen to demonstrate dependence of mature almond trees on annual uptake of soil nitrogen. J. Plant Nutr. 7:975-990.

Weinbaum, S.A. and T.T. Muraoka. 1986. Nitrogen redistribution from almond foliage and pericarp to the almond embryo. J. Amer. Soc. Hort. Sci. 111:224-228.

Westwood, M.N., L.P. Batjer, and H.D. Billingsley. 1967. Cell size, cell number, and fruit density of apples as related to fruit size, position in cluster and thinning method. Proc. Amer. Soc. Hort. Sci. 91:51-62.

Windus, N.D., V.G. Shutak, and R.E. Gough. 1976. $\mathrm{CO}_{2}$ and $\mathrm{C}_{2} \mathrm{H}_{4}$ evolution by highbush blueberry fruit. HortScience 11:515-517. 